JEFAS

24,47

4

Received 9 May 2018

Revised 18 November 2018

Accepted 2 January 2019

\section{The determinants of conventional banks profitability in developing and underdeveloped OIC countries}

\author{
Ahmad Al-Harbi \\ Saudi Arabia Ministry of Economy and Planning, Riyadh, Saudi Arabia
}

\begin{abstract}
Purpose - The purpose of this study is to investigate the effect of internal and external variables on the profitability of conventional banks operating on developing and underdeveloped countries, the Organization of Islamic Cooperation (OIC) states.

Design/methodology/approach - In this paper, the author uses ordinary least squares fixed-effects model on an unbalanced panel data set of all conventional banks operating in OIC countries (52 countries included from 57) over the period 1989-2008, 686 banks.

Findings - The results suggest that equity, foreign ownership, off-balance sheet (OBS) activities, real gross domestic product growth, real interest rate and concentration foster banks' profitability. In addition, the results showed that the banking sector development and loans will increase banks' profitability in the long run in the countries of the studies. In contrast, the study reported that deposits lower profitability. The study also revealed that GDP per capita, market capitalization and banks size have no impact on profitability.

Practical implications - The findings of this study have considerable policy implications. First, policymakers need to regulate nontraditional activities to avoid any financial crisis because banks in OIC countries are heavily engaged in nontraditional activities to boost its profit. Second, policymakers are advised to improve the deposit insurance system to insure the stability of the financial system as well as improving banks' profitability. Third, policymakers need to improve the efficiency of the stock market, maintain small banking system and encourage foreign investments in the banking system.

Originality/value - The paper adds to the literature on the commercial bank's profitability determinants. In particular, such study has not been conducted on OIC countries, and the study included all mainstream banks and incorporated the effect of deposit insurance system so far. Also, pure sample of conventional banks used as many conventional banks in OIC countries have Islamic windows or offer Islamic products. In addition, this study investigated the effect of OBS activities on net interest margin (NIM) because the studies that explored this interrelationship are limited especially for developing and under developed countries. The results showed that OBS activities contributed significantly and positively to return on assets and NIM. Moreover, this paper used a pure sample of conventional banks to avoid any biasness; see data section. Moreover, this study gives an idea about the economic situation and financial conditions of OIC countries during the period of the study.
\end{abstract}

Keywords Profitability, Conventional banks, External factors, Internal factors

Paper type Research paper

\section{Introduction}

The financial system has an outstanding role in channeling funds to investments efficiently to support economic growth resulting in the decrease of income inequality, especially in

(C) Ahmad Al-Harbi. Published in Journal of Economics, Finance and Administrative Science. Published by Emerald Publishing Limited. This article is published under the Creative Commons Attribution (CC BY 4.0) licence. Anyone may reproduce, distribute, translate and create derivative works of this article (for both commercial and non-commercial purposes), subject to full attribution to the original publication and authors. The full terms of this licence may be seen at http:// creativecommons.org/licences/by/4.0/legalcode 
developing and underdeveloped nations such as the members of Organization of Islamic Determinants of Cooperation (OIC) countries[1].

The key component in a financial system is banks. They work as intermediate between funds provider and those in need of funds contributing to economic growth. Also, banks play a role in the implementation of a country monetary policy. Thus, profitable banks will ensure the continuity of economic growth as well as the stability of the financial system.

Developing and underdeveloped countries are characterized by low gross domestic product (GDP) per capita, low growth rate, lack of proper market, lack of capital formation[2], low level of technology and skills and weak economies and regulations. The contribution of this paper is that it explored the determinants of banks' profitability in those countries, especially there is a lack of cross-country studies that investigated banks' profitability in developing and underdeveloped countries using a sample of all conventional commercial banks operating in 52 countries, members in OIC, for a long period (20 years). Another motivation is that there is no study before this that examined the determinates of banks profitability in the OIC countries using a sample of all banks operating on those countries. The recent studies that investigated the determinants of banks' profitability in the OIC countries did not include all the member countries and/or did not comprise all conventional banks on it (Sun et al., 2017; Rekik and Kalai, 2018; Yanikkaya et al., 2018). In addition, this study uses two measures of profitability and many explanatory variables. Also, OIC countries are the home of more than 90 per cent of Islamic banks in the world, and many of its conventional banks provide Islamic products; thus, other studies that used cross-country data could include banks with Islamic windows or Islamic banks which make their results bias. Moreover, the financial sector in OIC countries is still dominated by conventional banks (excluding Iran and Sudan, as their financial system is Islamized), even though Islamic banks share is increasing progressively. For instance, Islamic banking assets represent less than 10 per cent of total banking assets in Algeria, Egypt, Indonesia, Oman, Tunisia and Azerbaijan as of 1H2014 (Islamic Financial Services Board, 2015)[3]. The number of banks in a single country is small; see data section. Therefore, a cross-country study allows us to bring in more information to form a bigger data set of bank information. Accordingly, this considered additional motivation behind this study.

The factors affecting banks' profitability are categorized into two groups: endogenous and exogenous elements. In view of the above, I believe that the following internal factors need to be examined which are capital adequacy, loans, deposits, foreign ownership, overhead costs and off-balance sheet (OBS) activities. Regarding external factors, it is widely believed that GDP growth, GDP per capita, real interest rates, regulations and financial structure are the significant external factors that may affect banks' profitability.

This study found that deposits lower banks' profitability in contrast to that in developed countries. Also, the factors such as deposit insurance, market capitalization and banks size have no impact on banks' profitability which contradicts the majority literature on banks' profitability in developed countries. Moreover, the results indicate that the development of the banking sector will increase profitability in the long run.

Another important contribution of this study is that it investigated the interrelationship between non-tradition activities and net interest margin (NIM). This attributed to the limited number of studies that explored this interrelationship between NIM and non-tradition activities. The results of this study showed that non-tradition activities and NIM linked positively which contradicts the study conducted on developed countries. This study also gives an idea about the economic and financial environments of OIC countries during the study period (Table IV). 
JEFAS 24,47

The rest of the paper is organized as follows. Section 2 presents a literature review and theoretical development. Section 3 describes data and methodology. Sections 4 and 5 represent results and discussion, respectively, and finally, conclusion presented.

\section{Literature review and theoretical development}

The empirical literature divides factors that affect bank profitability into two categories: internal and external factors. For both categories, numerous explanatory variables have been proposed, depending on the type and aim of each study. Internal determinants of profitability can be classified into financial-statement variables and non-financial-statement variables, both of which fall under the control of bank management (Haron, 2004). External variables are beyond the control of bank management but reflect factors from the economic and financial structure and legal environment. According to Haron (2004), competition, regulation, concentration, market share, ownership, scarcity of capital, money supply, inflation and bank size are the most widely discussed external variables.

However, studies on the determinants of banks' profitability are conducted on banks in developing countries mainly on the banking sectors in the USA and Europe. For example, Berger (1995a, 1995b), Abreu and Mendes (2001), Athanasoglou et al. (2006), Chiorazzo and Milani (2011), Growe et al. (2014), Petria et al. (2015), Menicucci and Paolucci (2016), Korytowski (2018) and Yüksel et al. (2018). While the studies that explored the determinates of commercial banks' profitability in OIC countries are limited and mainly are single country studies. For example, Ben Khedhiri et al. (2008; Tunisia), Ferrouhi (2017; Morocco) and Yao et al. (2018; Pakistan).Table I lists the results of some of the studies that conducted on commercial banks' profitability.

\subsection{Theoretical development}

\subsubsection{Internal factors}

2.1.1.1 Capital adequacy. Banks with a high capital ratio are considered to be insured against bankruptcy, to have access to cheap funds, to be more flexible in pursuing business opportunities and to have the ability to absorb any unexpected losses. Thus, higher profitability can be expected for these banks, and this is confirmed by many studies (Table I). However, a negative relationship between profitability and the high capital ratio can be expected given that well-capitalized banks are considered safer because they take less risk, and therefore, according to financial theory, produce lower returns. The study conducted by Saona (2016) found a negative relationship between profitability and capital adequacy.

Although the empirical evidence on the relationship between the capital ratio and profitability is not conclusive, it seems to lean toward a positive effect. Therefore, for this study, a positive relationship between capital adequacy and profitability is hypothesized.

2.1.1.2 Loans. The effect of loans on profitability is expected to be positive, as the greater the number of loans, the higher the income for banks. A large body of banking literature, namely, Heffernan and Fu (2008), Sufian (2012) and Menicucci and Paolucci (2016) showed that loans contribute to banks' profitability. However, the increase in loans could escalate the costs of funds leading to a negative correlation between profitability and loans. Furthermore, banks' lending activities are sensitive to economic conditions and during slow periods more loans are expected to default leading to a negative impact on profitability. Therefore, there are reasonable theoretical reasons to expect either a positive or negative effect on loans on profitability. Kosmidou et al. (2005) and Heffernan and Fu (2008) found a negative relationship between loans and profitability.

Based on the above, there are reasonable theoretical reasons to expect a negative effect for loans on profitability. 


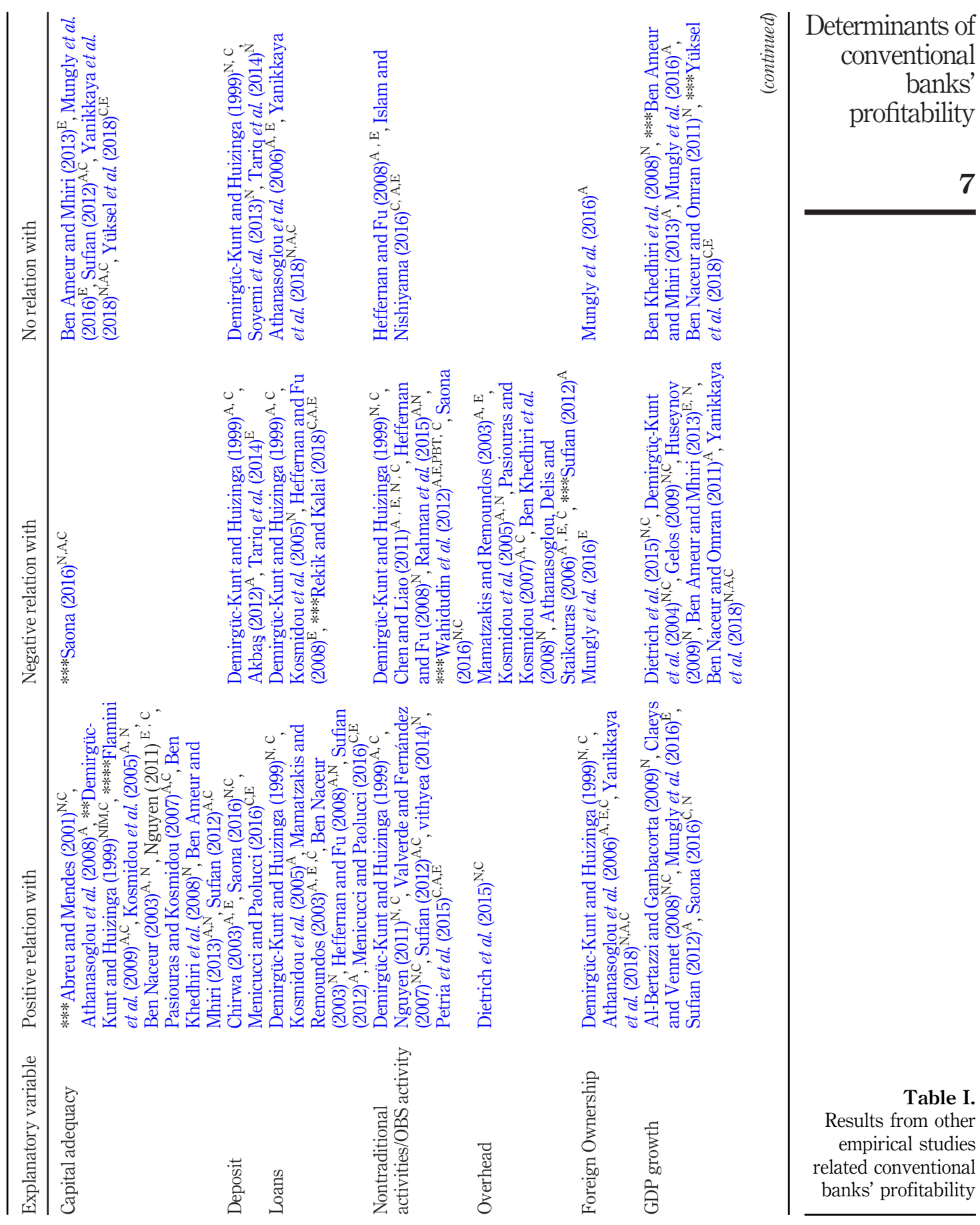



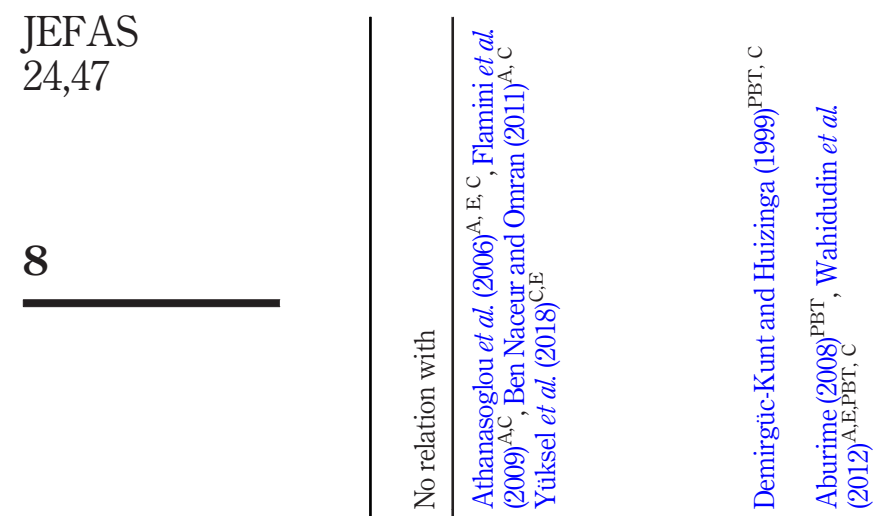

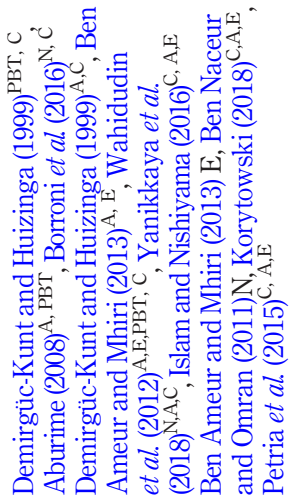

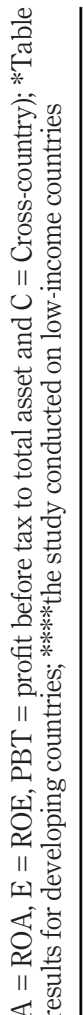

胥

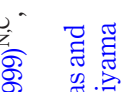

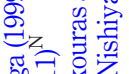

:

要远

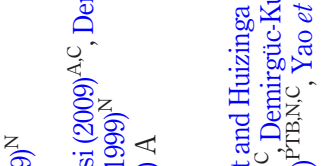

望势

范

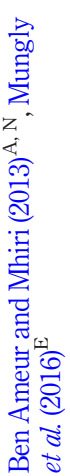

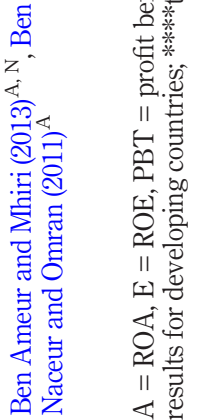

晃

武它

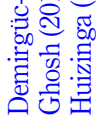

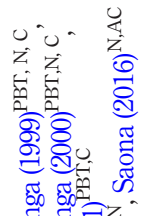

芳

秀. 공

范范

资 0 -

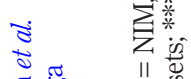

चั0.

安

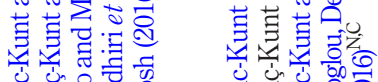

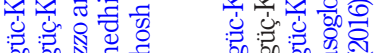

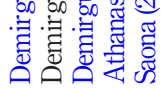

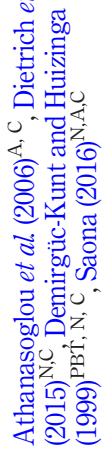

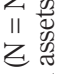

ब.

더월

.

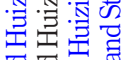

चี च

용 푱

壳

苞

票

菅

ㅇำ

흐. 을

离

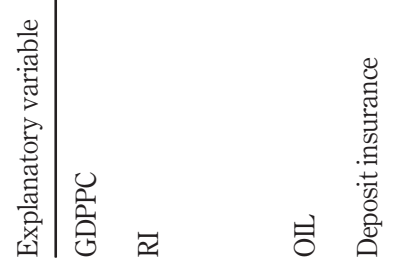

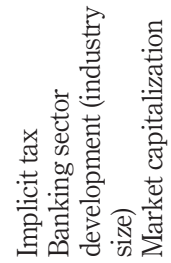

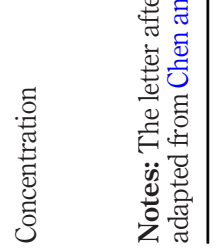


2.1.1.3 Deposits. Deposits are banks' primary sources of funds and perhaps the cheapest, so this variable can be expected to affect banks' profitability positively as long as there is a demand for loans. Chirwa (2003), Saona (2016) and Menicucci and Paolucci (2016) show evidence that deposits improve banks' profitability. On the other hand, the lack of loan demand or poor management of the bank's liquidity could lead to a negative effect because these deposits would be costlier for banks in terms of the required branch networking and remuneration. The results of Akbas (2012) and Tariq et al. (2014) is in line with this. Literature also reported an insignificant relationship between deposits and profitability

Determinants of conventional banks' profitability

(Demirgüc-Kunt and Huizinga, 1999; Soyemi et al., 2013; Tariq et al., 2014). In this study, I hypothesize a negative relation between profitability and deposits.

2.1.1.4 Cost management. The results of previous studies on the effect of this variable on banks' profitability are mixed. A negative correlation indicates that efficient banks are expected to operate at lower costs, but a positive relationship can be expected, as banks with high operating costs are more likely to have high-interest spread. Also, a positive relationship can be achieved if banks manage to transfer part of their cost to their customers. See Table I for the studies that included cost management in their investigation of banks' profitability.

In this study, I predict a negative relationship between cost management and profitability because many of the countries in this study have weak economies, meaning that banks must pass their operating costs on to their depositors and lenders over the long run.

2.1.1.5 Off-balance sheet activities. Banks engage in OBS activities hoping to earn additional income to compensate for the decline of its earnings from traditional activities. The empirical findings of Valverde and Fernández (2007), Nguyen (2011), Sufian (2012), Vithyea (2014) and Petria et al. (2015) provide evidence for that. Conversely, banks that are heavily involved in nontraditional activities are subject to higher risks (market and macroeconomic) which may lead to lower profitability. This supported Chen and Liao (2011), Wahidudin et al. (2012), Rahman et al. (2015) and Saona's(2016) study.

In this study, other operating income to total assets (OOI) used as a proxy of OBS[4], I predict a positive relationship between OBS and profitability (return on assets [ROA] and NIM).

2.1.1.6 Foreign ownership. Foreign ownership could affect banks' profitability positively because foreign banks possess superior technology, have high governance standards, are better in mitigating risk and benefit from special tax breaks. The cross-country study conducted by Yanikkaya et al. (2018) provide evidence for this argument. In contrast, foreign ownership could affect banks' profitability negatively because foreign banks are affected not only by the economic and financial conditions in the countries where they operate but also by the situations in their home countries. Mungly et al. (2016) reported a negative relationship between foreign ownership and banks' profitability.

Furthermore, the foreign-owned banks in this study come mainly from developing countries, which tend to have lesser technology and lower governance standards. From the above, I expect this variable to have a negative effect on profitability.

2.1.2 External factors

2.1.2.1 Real gross domestic product growth. Economic development is measured by GDP per capita (2005 prices, in thousands, USD) and reflects differences in many factors that may omit from regression and affect banks' profitability such as the mix of banking opportunities and regulations. Higher economic efficiency can be associated with economic development, thus leading to better profitability (Table I). From another perspective, higher competition can decrease bank profits, and therefore, a negative correlation between GDP 
JEFAS

24,47

10

per capita and banks' profits can be expected. Numerous studies reported a negative correlation between profitability and GDP growth (Ben Ameur and Mhiri, 2013; Ben Naceur and Omran, 2011; Yanikkaya et al., 2018).

In this study, it is expected that the relationship between profitability and GDP per capita will be positive because of low competition in the countries of this study, developed and less developed countries.

2.1.2.2 Economic development. The GDP per capita growth proxies' business cycle fluctuations. The effect of this variable is not restricted; during recessions, the quality of loans deteriorates, which increases defaults and leads to lower profitability. The negative association between economic development and banks' profitability is reported by Demirgüc-Kunt and Huizinga (1999) and Ben Naceur and Omran (2011). However, the upturn of the economy increases the demand on loans causing bank profitability to improve. Bogdan and Roman (2015) results are in line with this. I expect this variable will affect banks' profitability positively.

2.1.2.3 Real interest rate. The large volume of literature, Table I, shows that there is a positive relationship between interest rate and banks' profitability. Meanwhile, the increase of interest rate discourages firms and people from borrowing resulting in the decrease in banks' profits in the long run. Staikouras and Wood (2003), Noman et al. (2015) and Islam and Nishiyama's (2016) results are in line with this argument. This study predicts that the interest rate will affect banks' profitability positively in developing and underdeveloped countries.

2.1.2.4 Tax. This paper follows Demirgüc-Kunt and Huizinga (1999) and Hassan and Bashir's (2003) study in using explicit and implicit taxes to show the ability of banks to allocate their portfolios to minimize their taxes. Also, this variable is included to capture the effects of regulations on the banking industry:

- Explicit taxes (TAX) are measured by dividing taxes by profit before tax.

- The variable for the implicit tax effect (RESDA) is calculated by multiplying consumer and short-term funds divided by total assets and then by reserve of the banking system (IFS Line 20) over the deposit of the banking system [IFS, Line $24+25)$. As indicated in Table I, most of the studies found a positive correlation between profitability and taxation. This study as well as expects the same results.

2.1.2.5 Deposit insurance. The deposit insurance (INR) variable is a dummy variable that is coded 1 if there is an explicit deposit insurance scheme and 0 otherwise even if the country's legislation offers some type of implicit insurance. The expected effect of deposit insurance schemes on banks' profitability is unclear because most of the countries in this study have an implicit insurance scheme, which implies that banks' deposits might not be secure if banks run into financial problems. Thus, banks will be more averse to risk which leads to lower profitability.

However, even under an implicit insurance scheme, many banks' managers are certain that the governments would not allow their banks to fail based on previous experiences (some banks in Egypt, Kuwait and Saudi Arabia did have problems in the past, and their governments bailed them out). This would, theoretically, lead banks to take more risks to increase their profits causing a positive effect. However, a negative impact is expected on profitability in this study because of the combined effect of no explicit deposit insurance scheme and the risk-taking behavior of banks.

Based on the aforementioned argument, I predict a negative correlation between deposit insurance and banks' profitability. 
2.1.2.6 Oil shocks. Oil prices are an important determinant here because about 50 per cent of the countries in this study are oil producers, and some of them such as Nigeria and some countries in the Middle East and North Africa (MENA) region are major oil producers. Many of those countries rely heavily on oil exports, and thus, a relationship between the oil variable and banks' profitability is expected.

However, this variable is not included in previous country studies (Ben Khediri and BenKhedhiri, 2009; Demirgüc-Kunt and Huizinga, 1999; Hassan and Bashir, 2003). Only three studies have considered this variable in an international investigation of bank profitability. The first study is by Poghosyan and Hesse (2009) on countries in the MENA region. The sample is divided into conventional, Islamic and investment banks. The second study is by Zantioti (2009) and focuses on Islamic banks. The third study is by Imam and Kpodar (2010) and examines the diffusion of Islamic banks. It seems intuitive that the impact of oil prices would be positive for banks located in countries that are net exporters because the financial position of banks and their customers tends to improve with high oil prices. Furthermore, countries located in MENA region that are net oil importers experience positive influences on their GDP and higher profitability in their banking systems because of increases in deposits and financial activities.

Many of these deposits come indirectly via trade with net-oil-exporting countries and money transfers from expats working in those countries (Abeysinghe, 2001; Berument et al., 2010). Net-oil-importing countries, which are not located in the MENA region, face challenges in controlling the effects of high oil prices. As a result, businesses, consumers and the government's budget are affected adversely, contributing to slow economic growth and lower bank profits because of more loan defaults and less demand for them. Moreover, the decline in oil prices in net-oil-exporting countries may not reduce banks' profitability because governments and major national companies borrowing in deficit times may create "oligopsony" (Essayyad et al., 2003).

On the other hand, low oil prices could make banks more averse to risk, which generally can lead to lower profits for banks located in oil-exporting countries, and the opposite may occur in net oil-importing countries. Poghosyan and Hesse (2009) find an indirect relationship between oil shocks and the profitability of conventional, Islamic and investment banks in major oil-producing MENA countries, and in that study, the indirect relationship is channeled through macroeconomic and institutional variables. Additionally, in studies of Saudi banks, Essayyad and Madani (2003) and Essayyad et al. (2003) find a positive relationship between profitability and oil prices. Imam and Kpodar (2010) support their findings. In the present study, I hypothesize a positive relationship between oil shocks and banks' profitability.

2.1.2.7 Stock market capitalization. The ratio of stock market capitalization to GDP is used to capture the effect of the development of a country's stock market on bank profitability. A positive effect is expected for this variable because developed stock markets increase the information available to banks which will allow them to improve their risk assessments of the borrowers. Furthermore, in developing and underdeveloped countries, the growth of stock markets tends to encourage people to obtain loans from banks to speculate in the stock market, and this eventually increases banks' profits. Also, banks benefit from the fees that come from managing their customers' portfolios which are mainly composed of stocks.

On the other hand, the stock market could affect banks' profitability negatively, as the stock market substitutes banks as a source of finance. The study conducted by Borroni et al. (2016) revealed that after the recent financial crisis, stock market linked negatively to banks' profitability (ROA, return on equity [ROE] and NIM), and the results were significant in case 
JEFAS

24,47

of ROA and ROE. I predict a negative relationship between banks' profitability and stock market capitalization.

2.1.2.8 Banking sector development (industry size). The banks' assets scaled by GDP ratio is used to capture the banking sector development. The larger the banking sector, the higher the competition among banks leading to lower profitability and margins. DemirgücKunt and Huizinga (1999) found a negative relation between profitability (ROA and NIM) and banking sector development, especially in developing countries. On the other hand, large banking sectors bring more opportunities and reduce costs leading to higher profitability and margins. Ghosh (2016) reported a positive relationship between profitability (ROA) and industry size but the opposite for margin.

Based on the aforementioned arguments, I expect a positive relation between banks' profitability and the banking sector development.

2.1.2.9 Size. This variable is used to capture the effects of economies or diseconomies of scale in the banking sector. The former lead to a positive relationship between size and profitability, whereas the later lead to a negative relation. In the literature, in general, the influence of the bank's size on profitability is positive (Demirgüc-Kunt and Huizinga, 1999; Athanasoglou et al., 2006; Saona, 2016). Thus, this study predicts a positive correlation between profitability and size, especially that the banks in the sample are small.

2.1.2.10 Concentration. The term concentration originated from structure-conductperformance theory, which indicates that high concentration is positively related to profitability. The efficient-market or efficient-structure hypothesis contradicts structureconduct-performance theory; specifically, the efficient-structure hypothesis suggests that firms with superior efficiency will obtain a large market share, and as consequence, the market will become more concentrated. Therefore, higher concentration does not necessarily imply market power, and consequently, the relationship between concentration and profitability does not have to be positive.

Both sides of this debate are reflected in the empirical literature. For instance, DemirgüçKunt and Huizinga (2000) find positive and significant relationships between profitability (ROA and NIM) and concentration. However, Ben Ameur and Mhiri (2013) find a significant but negative relationship (ROA and NIM). This study predicts a positive relationship between profitability and concentration.

\section{Data, methodology and variables}

In this section, all the issues related to the data, methodology and variables will be discussed.

\subsection{Data and methodology}

This study extracts cross-country bank-level data from the income statements and balance sheets of 730 banks drawn from the commercially available (and widely used) BankScope database (Table II). The period of the study, 1989-2008, is chosen to omit the effect of the world financial crisis[5].

The sample reduced from 730 to 686 banks. This is related to the unavailability of data for some countries, and other countries have only Islamic banks (Iran and Sudan); the number of countries included is 52 out of 57 because of the aforementioned constraints[6]. Also, mainstream banks with Islamic windows and converted banks (converted period) are excluded from our sample.

To be noted that this study used different sources such as banks websites and data from central banks to make sure that our sample is made of pure conventional banks because BankScope database is not comprehensive on its classification. For instance, it classifies 


\begin{tabular}{|c|c|c|c|c|c|}
\hline No. & Country & Islamic banks & Conventional banks & Total no. of banks ${ }^{\mathrm{a}}$ & $\begin{array}{l}\text { Determinants of } \\
\text { conventional }\end{array}$ \\
\hline 1 & Afghanistan & & 3 & 3 & banks' \\
\hline 2 & Albania & & 11 & 11 & cofitahilit \\
\hline 3 & Algeria & 1 & 12 & 13 & promlabinty \\
\hline 4 & Azerbaijan & & 16 & 17 & \\
\hline 5 & Bahrain & 6 & 6 & 17 & \\
\hline 6 & Bangladesh & 5 & 27 & 33 & 13 \\
\hline 7 & Benin & & 8 & 8 & \\
\hline 8 & Brunei & 1 & 1 & 2 & \\
\hline 9 & Burkina Faso & & 9 & 9 & \\
\hline 10 & Cameroon & & 11 & 11 & \\
\hline 11 & Chad & & 3 & 3 & \\
\hline 12 & Djibouti & & 2 & 2 & \\
\hline 13 & Egypt & 2 & 18 & 26 & \\
\hline 14 & Gabon & & 5 & 5 & \\
\hline 15 & Gambia & 1 & 6 & 7 & \\
\hline 16 & Guinea & & 5 & 5 & \\
\hline 17 & Guyana & & 3 & 3 & \\
\hline 18 & Indonesia & 2 & 47 & 53 & \\
\hline 19 & Iran & 16 & & 16 & \\
\hline 20 & Iraq & 2 & 7 & 9 & \\
\hline 21 & Ivory Coast & & 11 & 11 & \\
\hline 22 & Jordan & 2 & 12 & 14 & \\
\hline 23 & Kazakhstan & & 22 & 22 & \\
\hline 24 & Kuwait & 3 & 7 & 9 & \\
\hline 25 & Kyrgyzstan & & 7 & 7 & \\
\hline 26 & Lebanon & 2 & 44 & 47 & \\
\hline 27 & Libya & & 8 & 8 & \\
\hline 28 & Malaysia & 12 & 24 & 36 & \\
\hline 29 & Maldives & & 1 & 1 & \\
\hline 30 & Mali & & 9 & 9 & \\
\hline 31 & Mauritania & 1 & 6 & 7 & \\
\hline 32 & Morocco & & 10 & 10 & \\
\hline 33 & Mozambique & & 9 & 9 & \\
\hline 34 & Niger & & 5 & 5 & \\
\hline 35 & Nigeria & & 11 & 11 & \\
\hline 36 & Oman & & 6 & 6 & \\
\hline 37 & Pakistan & 6 & 24 & 30 & \\
\hline 38 & Palestine & 1 & 2 & 3 & \\
\hline 39 & Qatar & 3 & 5 & 8 & \\
\hline 40 & Saudi Arabia & 3 & 7 & 11 & \\
\hline 41 & Senegal & 1 & 10 & 11 & \\
\hline 42 & Sierra Leon & & 8 & 11 & \\
\hline 43 & Sudan & 24 & & 24 & \\
\hline 44 & Suriname & & 2 & 2 & \\
\hline 45 & Syria & 2 & 9 & 11 & \\
\hline 46 & Tajikistan & & 3 & 3 & \\
\hline 47 & Togo & & 6 & 6 & \\
\hline 48 & Tunisia & 1 & 16 & 17 & Table II. \\
\hline \multirow[t]{2}{*}{49} & Turkey & 4 & 34 & 38 & Number of banks by \\
\hline & & & & (continued) & \\
\hline
\end{tabular}




\begin{tabular}{|c|c|c|c|c|}
\hline No. & Country & Islamic banks & Conventional banks & Total no. of banks ${ }^{\mathrm{a}}$ \\
\hline 50 & Turkmenistan & & 1 & 1 \\
\hline 51 & Uganda & & 11 & 11 \\
\hline 52 & UAE & 5 & 8 & 19 \\
\hline 53 & Uzbekistan & & 14 & 14 \\
\hline 54 & Yemen & 4 & 4 & 8 \\
\hline Total & & 110 & 576 & 699 \\
\hline
\end{tabular}

Notes: ancludes the windows of conventional banks and the years before and during conversion for banks converted to Islamic banking. Banks with less than two years of data excluded

Table II. Source: Author's calculations based on BankScope data

some Islamic banks as conventional banks and vice versa and does not indicate if a bank is converted from conventional banking to Islamic banking.

Regarding methodology, this study adopted, with some modification, the model and methodology used by Demirgüc-Kunt and Huizinga (1999)[7].

A linear equation is used to perform the regression analysis[8]. The model used for this analysis is represented by equation (1):

$$
\mathrm{P}_{i j t}=\alpha_{0}+\alpha_{i} \mathrm{~B}_{i j t}+\mathrm{B}_{j} \mathrm{X}_{j t}+\gamma_{t} \mathrm{~T}_{\mathrm{t}},+\delta_{j} \mathrm{C}_{j}+\varepsilon_{i j t}
$$

where $\mathrm{P}_{i j t}$ is performance (either ROA or NIM) for bank $i$ in country $j$ at time $t$; $\mathrm{B}_{i j t}$ represents bank variables for bank $i$ in country $j$ at time $t$; $\mathrm{X}_{j t}$ represents country variables for country $j$ at time $t ; \mathrm{T}_{t}$ and $\mathrm{C}_{j}$ are time and country dummy variables; $\varepsilon_{i j t}$ is an error term.

The two-way fixed-effects (FE) model has been chosen because the Hausman test shows that the FE (cross-section and time) model is consistent. Further, our sample is not random and contains almost all the conventional banks in the countries of the study.

Heteroscedasticity is not present in our sample based on white test[9], and the data cleaned from outliers. In addition, Durbin-Watson's results indicated that multicollinearity is not significant.

In selecting variables, to avoid multicollinearity problems, if any variable has a multicollinearity problem will be dropped.

\subsection{Measures of bank profitability}

In this study, two measures of performance are used: ROA and NIM. ROA is defined as profit after tax to total assets and shows the profit earned per dollar of assets[10]. For this study, NIM is defined as the net interest revenue income over earning assets and measures interest spread for conventional banks.

\subsection{Determinants of bank profitability}

This section describes the determining factors of bank profitability, which is divided into internal and external factors. External factors are further divided into variables encompassing macroeconomic factors, oil shocks, taxation, deposit insurance schemes and 
financial structure. Following Bourke's (1989) who included internal variables in his crosscountry study on banks' profitability, many researchers followed his footsteps and used internal variables in their studies on banks' profitability in single or multiple countries (Table I). Following these studies, numerous internal variables are used in this paper to investigate the profitability of banks in OIC countries.

The literature suggests that external factors such as macroeconomic trends, stock market development and policy influence banks just like they affect any other type of firm. In this study, several sets of external determinants are examined: national macroeconomic conditions, oil shocks, taxation, deposit insurance and financial structure. Table III displays the variables used to measure banks' profitability as well as the variables employed to examine the determinants of banks' profitability.

The variables used in this study illustrated in Table III.

\begin{tabular}{|c|c|c|}
\hline Variable & Description & $\begin{array}{l}\text { Expected } \\
\text { sign }\end{array}$ \\
\hline \multicolumn{3}{|c|}{ Dependent variables } \\
\hline ROA & Bank's before-tax profits divided by total assets & \\
\hline NIM & $\begin{array}{l}\text { Net interest income divided by total assets } \\
\text { Independent variables }\end{array}$ & \\
\hline \multicolumn{3}{|c|}{ Bank characteristics } \\
\hline $\mathrm{EQ} / \mathrm{TA}_{\mathrm{t}-1}$ & Equity divided by lagged total assets & + \\
\hline LOTA & Loans divided by total assets & - \\
\hline DSTA & Consumer and short-term funds divided by total assets & - \\
\hline OHTA & Overhead divided by total assets & - \\
\hline OOI & Other operating income divided by total assets & + \\
\hline FRGN & Dummy, equal 1 if a bank has at least $50 \%$ foreign ownership otherwise 0 & - \\
\hline \multicolumn{3}{|c|}{ Macroeconomic } \\
\hline GDPPC & GDP per capita (constant 2005 [USD] prices) & + \\
\hline Growth rate & GDP per capita (constant 2005 [USD] prices) growth rate & + \\
\hline \multicolumn{3}{|l|}{ Oilshock } \\
\hline OIL & Annual change on oil prices (constant 2005 [USD] prices) & + \\
\hline \multicolumn{3}{|l|}{ Taxation } \\
\hline TAX & Tax divided by before tax profit & + \\
\hline RES & $\begin{array}{l}\text { Reserve of the banking system over deposit of the banking system multiplied by } \\
\text { customer and short-term funding over assets for each bank }\end{array}$ & + \\
\hline \multicolumn{3}{|c|}{ Deposit insurance } \\
\hline INR & Dummy, equal one if the country has explicit deposit insurance and zero otherwise & - \\
\hline \multicolumn{3}{|c|}{ Financial structure } \\
\hline MACP & Market capitalization over GDP & - \\
\hline BNK & Bank's assets over GDP & + \\
\hline Assets & Bank's total assets (constant 2005 [USD] prices) & + \\
\hline $\mathrm{C} 3$ & The assets of the largest three banks divided by the assets of the banking system & + \\
\hline
\end{tabular}

Note: *All independent variables interacted with GDP per capita (constant 2005 [USD] prices) except for inflation

\section{Determinants of conventional banks' profitability}

\section{$-$}


JEFAS

24,47

16

光

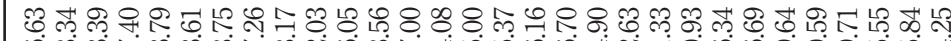

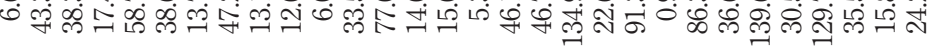

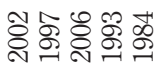

\section{怘}

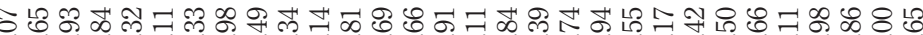

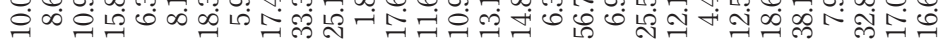

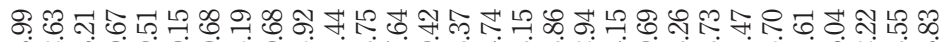

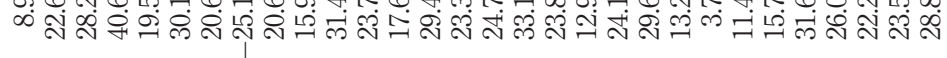

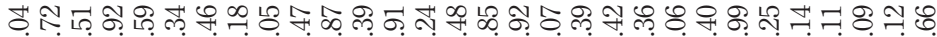

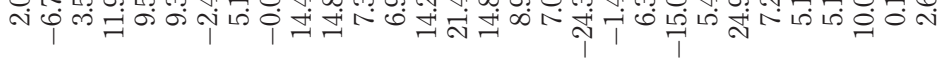

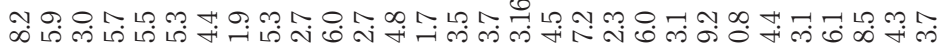

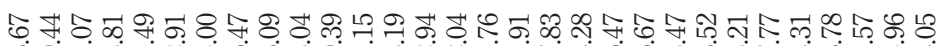

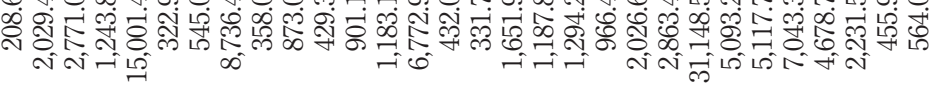

Table IV. Economic and institutional indicators in OIC countries

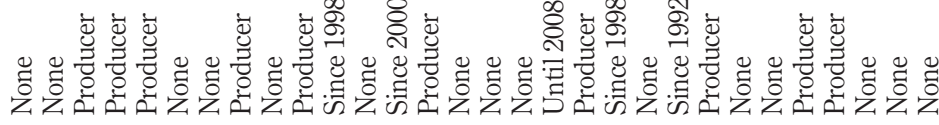

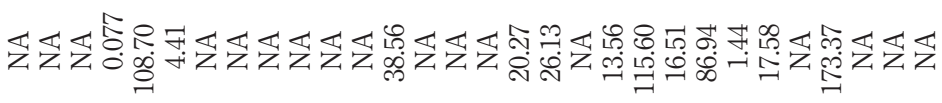

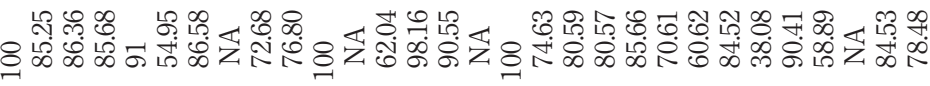



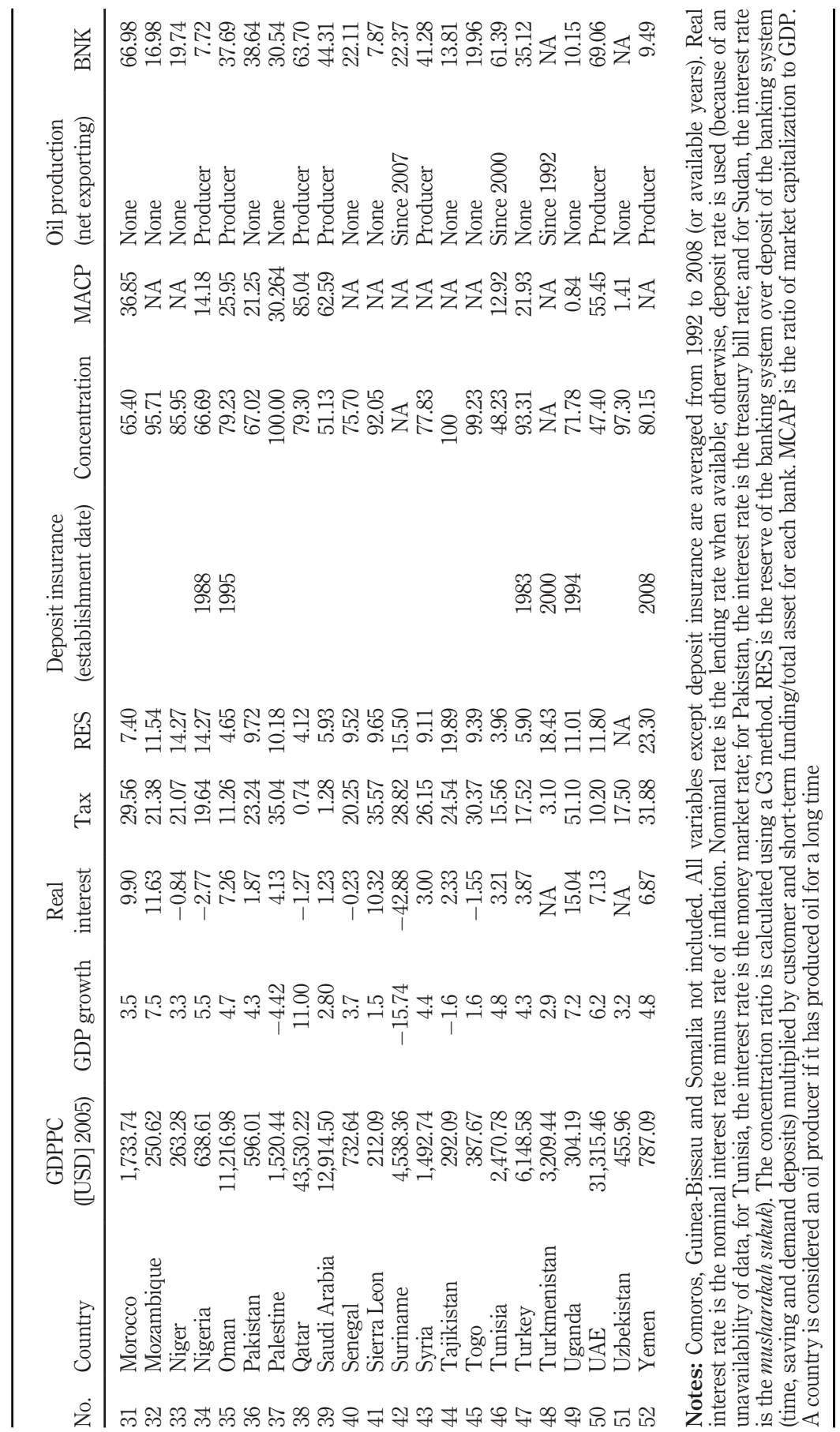
Determinants of conventional banks' profitability


JEFAS

24,47

\section{8}

Table V.

Determinants of ROA

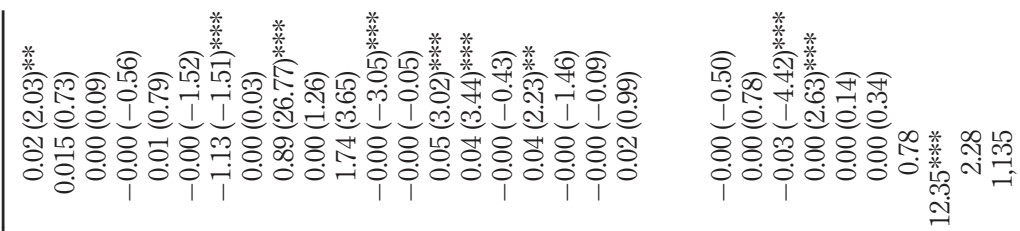

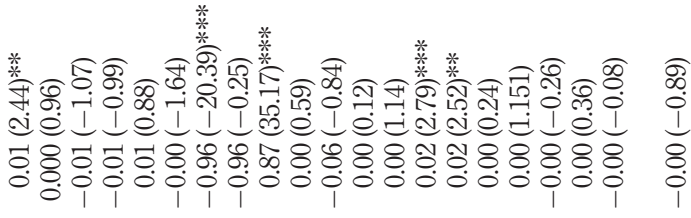

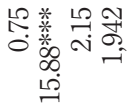

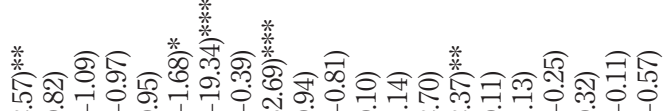

$+$

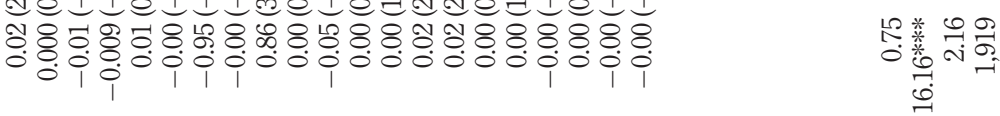

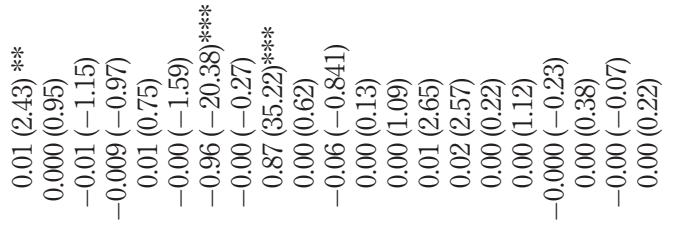

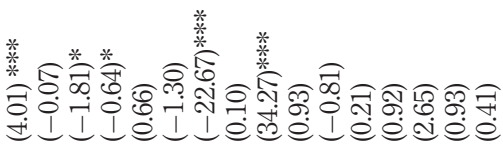

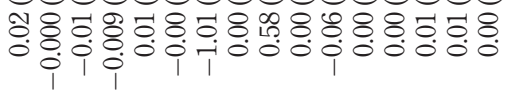

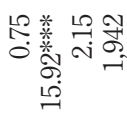

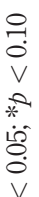

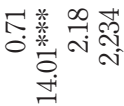

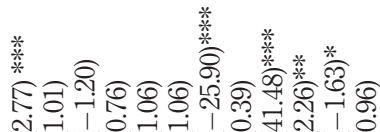

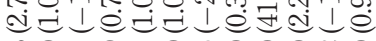

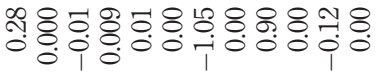

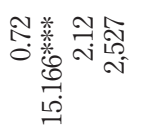

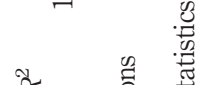

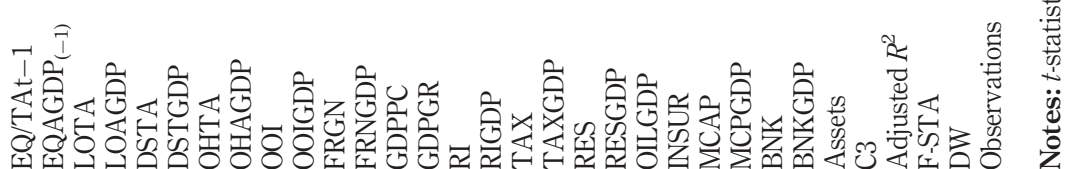




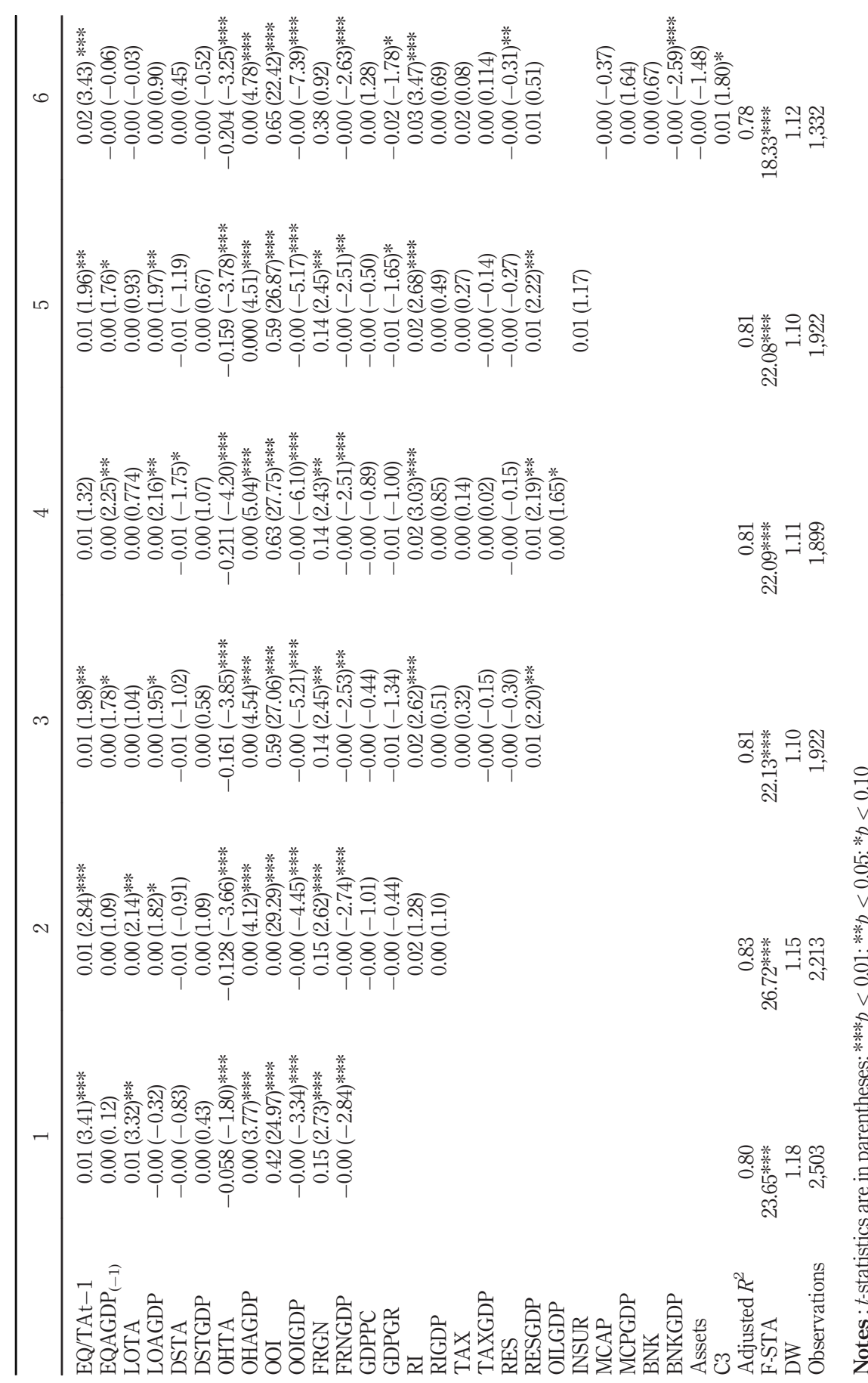

Determinants of conventional banks' profitability

19

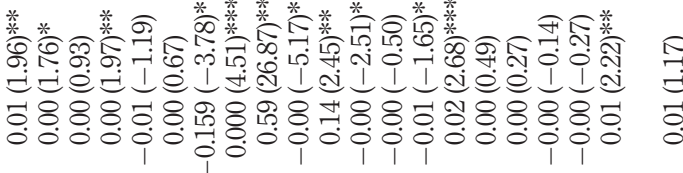

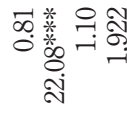

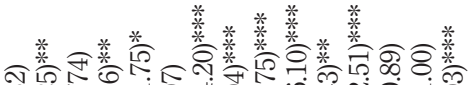

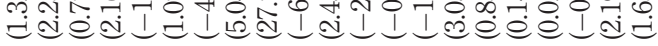

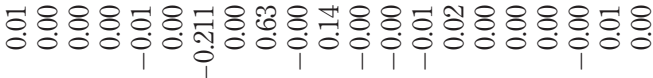

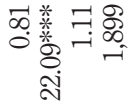

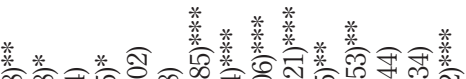

\%

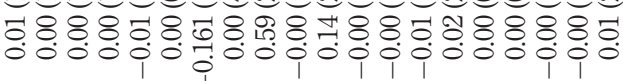

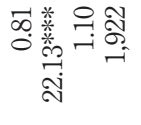

$\stackrel{2}{\circ}$

客

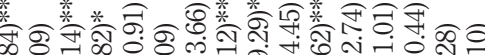

aंن

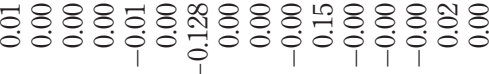

里

ฝ่

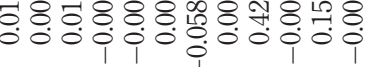

Table VI.

Determinants NIM 
JEFAS

24,47

\section{Results}

Table IV represents the descriptive statistics of the variables, and Tables V and VI represent the regression results of ROA and NIM, respectively.

\section{Discussion of results}

This section provides the summary statistics of the variables used in the study, and the analysis of the performance of the banks in OIC countries.

\subsection{Descriptive statistics}

The ratios and indicators in Table IV give an idea about the economic and financial environments in which the banks in this study operate. Columns 2 through 3 in the table present the three macroeconomic variables: GDP per capita, GDP growth rate and real interest rate. GDP per capita was measured in 2005 prices (USD) and was highest in Qatar $(43,530.22)$ followed by the UAE $(31,315.46)$ and then by Kuwait $(31,148.52)$. The lowest per capita GDP was for Afghanistan, with a value of 208.671. In general, the countries in this study had low per capita GDPs. GDP growth varies significantly throughout the sample, ranging from a high of 11 per cent per year in Qatar to a low of -15.74 in Suriname. The real interest rate is highest in Kyrgyzstan (24.99) and lowest in Suriname (-42.875). Albania, Benin, Burkina Faso, Iraq, the Ivory Coast, Kazakhstan, Niger, Nigeria, Qatar, Senegal and Togo have negative real interest rates.

Columns 4 and 5 of Table IV show the tax and reserve ratios. These ratios are indicators of the financial market's structure in each country. The tax ratio (tax values divided by profit before taxes for each bank) is highest in Uganda (51.10 per cent), followed by Azerbaijan (40.67 per cent), and Sierra Leon (35.57). The lowest ratios are negative in a direction primarily because BankScope counts deferred taxes in its tax data. Also, the ratio is related to the negative values of the profit-before-tax variable. Only one country has a negative sign (Brunei, -25.19). The reserve ratio (RES), which is used as a measure for implicit taxes, is calculated by dividing the reserves of the banking system by the deposits of the banking system (time, savings and demand deposits), and then multiplying the result by a customer and short-term funding over total assets for each bank. The highest RES value is observed in Iraq (56.72 per cent), followed by Libya (38.11 per cent) and then Cameroon (33.34 per cent). The lowest value is 1.811 (Djibouti). The RES values for Maldives, Jordan, Chad and Yemen range from 32.86 to 23.3 per cent. This is an indication that the majority of the countries in the study sample are experiencing financial repression.

The implementation year of the deposit insurance scheme is represented in Column 6 of Table IV. In the estimation, the variable is coded 1 if such an insurance scheme is present $(0$ otherwise). Several countries offer some type of implicit insurance, and even when this is the case, the dummy variable is coded 0 . Only 17 countries have a deposit insurance scheme, and some of them have just introduced the scheme toward the end of the study period. For this study, concentration ratio is defined as the ratio of the three largest banks' assets to total banking sector assets (as shown in Column 7 of the table). The concentration ratio is 100 per cent in Chad, Guyana, Palestine and Tajikistan, followed by 99.23 per cent in Togo and 98.16 per cent in Gabon. The ratio is lowest in Lebanon (38.08 per cent). The ratio for other countries in the sample ranges from 97 to 47 per cent. These figures are very high. The ratio of market capitalization to GDP is highest in Malaysia (173.37 per cent), followed by Jordan (115.70 per cent) and then Bahrain (108.70 per cent). The ratio is lowest in Azerbaijan (0.08 per cent). 
The oil production situation for the countries in the sample is shown in the last column of Determinants of the table. The countries producing oil for long more than 20 years are categorized as producers; otherwise, the date that a country became a producer is indicated.

The oil-producing countries comprise about half of the sample. However, the year when exporting began varies by country. Also, some countries such as Tunisia are not net exporters or net importers. All of those countries have been exporting oil since the 1980s.

The ratio of banks assets to GDP (BNK) is highest in Lebanon (139.64 per cent) and lowest in Kazakhstan ( 0.93 per cent), the majority of the countries has a low ratio.

Finally, it is clear from the descriptive statistics that the countries in the study sample have different economies, financial structures, banking regulations and levels of development. However, in general, they have low GDPPC, low GDP growth, lack of proper market and high concentrated banking sector, and the majority of the countries are oil producers.

\subsection{Regression}

The first variable Equity divided by lagged total assets (EQ/TAt-1; profits if not paid out in dividends will have a contemporaneous impact on bank equity, thus total assets lagged by one period to correct for this effect) has a highly significant and positive relationship with ROA and NIM. This finding supports the argument that well-capitalized banks can charge more for loans, pay less on deposits and pursue more business opportunities because they face a lower risk of bankruptcy (Srairi, 2009). This result is consistent with many studies findings such as Abreu and Mendes (2001) and Sufian (2012). The interaction of this variable with GDPPC has the same sign but only significant in the case of NIM.

On the other hand, loans (LOTA) have a weak negative effect on ROA (Column 2); nonetheless, the effect is positive and slightly highly significant for NIM (Columns 1 and 2). The interaction of LOTA with GDPPC is only significant in the case of NIM (Columns 3, 4 and 5), positive. The results here are parallel to Demirgüc-Kunt and Huizinga's (1999) findings. These outcomes suggest that weak economic conditions reduce the number of loans issued and increase loans default causing banks' profits to drop; however; the improvement in the economic settings will increase banks' profits in the long run.

The ratio of short-term funding to total assets (DSTA) in contrary to this paper predication has no meaningful relationship with ROA and NIM (weak negative relation with NIM in Column 4). This indicates that the banks in developing and low-income countries have low deposits, and it is costly to banks in term of branch network. Another reason that deposits lower banks interest margin that banks in developing and less developed countries offer high returns on deposits to attract customers. Moving to the effect of overheads on banks' profitability, the results show a negative correlation between this variable and profitability (ROA and NIM), and the improvement of the economic conditions allows banks to pass overhead costs to its customers. These results are in line with many studies as seen in Table I.

As expected, the impact of OOI on profitability (ROA and NIM) is positive and highly significant in all columns. It is also be noted that the interaction of this variable with GDPPC is significant with NIM and with a negative sign. This suggests that banks in developing and less developed countries depend on nontraditional activities to boost their profits because they operate in weak economies. Vithyea's (2014) study, Cambodian banks, suggested that there is a trade-off between non-interest income and interest margin as during economic downturns, banks depend on nontraditional activities and vice versa.

The final bank characteristic, foreign ownership, in general, has a positive link with profitability (ROA and NIM), and the same applies to the interaction of this variable with 
JEFAS

24,47

GDPPC but with a negative sign. Thus, it can be said that banks with foreign ownership gain profit in developing and less developed countries because they bring better management techniques and technologies, and this advantage decline with the economic development of those countries. The results are consistent with Demirgüc-Kunt and Huizinga's (1999) conclusions.

Moving to the effect of macroeconomic variables on banks profitability. The first macroeconomic variable is GDPPC, and contrary to this paper, expectation has no effect on banks' profitability in developing and less and developed countries. The results are consistent with Ben Naceur and Omran (2011) who studied the performance of banks in developing countries (MENA region). Meanwhile, the growth rate has a diverse effect on ROA and NIM. In one hand, the growth rate linked positively with ROA through the entire regression but significant in Columns 5 and $6(p<0.01)$. In the other hand, this variable correlated negatively but weakly (Columns 5 and 6) with NIM. These results are in alignment with well-documented literature (Table I) that economic growth will improve banks' profitability in the long run. The final macroeconomic variable is real interest rate which constructed by subtracting interest rate from inflation rate. The results show that real interest has a positive and highly significant correlation with ROA and NIM, and this is consistent with many studies as seen in Table I.

Next, the effects of taxation variables on banks' profitability will be discussed. The results show that direct taxes (corporate taxes; TAX) have inconsequential relation with ROA and NIM (except in Column 6 for ROA with a positive sign; $p<0.05$ ). This outcome supported by Aburime's (2008) study. In relation to implicit taxes (RES), the results are insignificant. However, the interaction of the variables (TAX and RES) with GDPPC is significant in case of RES and only for NIM (positive) in Columns 3, 4 and 5 at 5 per cent level. This indicates that banks in developing and less developed countries managed to pass some of its costs to its customers, and this is related to economic development. The outcome of this study contradicts the findings of Demirgüc-Kunt and Huizinga (1999).

In contrary to this paper, expectation deposit insurance had no effect on banks' profitability in developing and low-income countries, and the sign was negative for ROA and positive for NIM. This implies that the lack of deposit insurance scheme and mispriced scheme hinders banks' risk taken behaviour leading to lower profitability in the long run. The results of this study contradict Demirgüc-Kunt and Huizinga's (1999) findings.

The interaction of oil prices with GDPPC variable affected NIM positively at 10 per cent level. The effect on ROA is trivial and negative. The results of ROA are in line with Essayyad and Madani (2003); meanwhile, the results of NIM support Huseynov's (2009) findings. The findings of this study indicate that oil prices impact banks' profitability indirectly, and the weak effect could be related to the fluctuation of oil prices during the study period, and some of the countries are net oil importers.

The set of financial structure variables has an insignificant effect on banks' profitability in developing and less developed countries. The first variable in this set is stock market capitalization (MACP); this variable enters the regression with a negative sign for both of profitability variables but irrelevant. The same applies to the interaction of this variable with GDPPC but with a positive sign. These results suggest that capital markets and banks will complement each other in developing and underdeveloped countries in the long run, and this is related to economic development. The immaterial results here are supported by Demirgüc-Kunt and Huizinga (1999; ROA), Aburime (2008; ROA and PBT) and Borroni et al.'s (2016; NIM) findings. The second variable is banks assets to GDP (BNK) which impacted ROA negatively and significantly $(\phi<0.01)$, whereas its effect on NIM is positive but insignificant. The interaction of BNK with GDPPC is positive $(p<0.01)$ for ROA and 
negative for NIM ( $p<0.01)$. Referring to Table I, Ghosh (2016) and Demirgüc-Kunt and Huizinga (1999) findings are in contrast to this paper finds. Ghosh's (2016) results show that banks assets to GDP affected ROA positively and NIM negatively, whereas Demirgüc-Kunt and Huizinga's (1999) results revealed that this variable had a negative effect on ROA and NIM. The results of this study suggest that the development of the banking sector will reduce costs leading to higher profitability in long run for banks operating in developing and less developed countries. The effect of size is insignificant for ROA (positive) and NIM (negative), and this is in line with previous studies such as Yanikkaya et al. (2018) and Islam and Nishiyama (2016). Finally, the concentration had a positive effect on ROA and NIM, but the results are significant in the case of NIM $(p<0.10)$. This reveals that concentrated markets allow banks in developing and underdeveloped countries to earn monopolistic profits by increasing its interest margin. These results supported by many studies, for example, Athanasoglou et al. (2006) and Saona(2016).

\section{Conclusion}

The analyses of this study add significantly to the empirical literature related to the determinants of banks' profitability. The analysis reveals that internal factors contribute significantly to the profitability of mainstream banks in OIC countries specifically capital adequacy, loans, OBS activities and foreign ownership. Moreover, the external factors which are GDP growth, real interest rate, banking sector development and concentration contributed to banks' profitability in OIC countries.

Based on this paper findings, some policy and regulation implications can be driven:

- Banks in OIC countries depend on nontraditional activities to improve their profitability; thus, regulatory bodies must regulate nontraditional activities to avoid any crisis. Brunnermeier et al.'s (2012) study revealed that the components of nontraditional activities equally contribute to market risk.

- Deposits have minimal effect on mainstream banks' profitability. Therefore, governments need to encourage people to open banks accounts[11].

- Overhead costs reduced banks' profitability accordingly banks' management must implement procedures to reduce overhead costs.

- Foreign ownership has a positive impact on the financial sector in OIC countries; hence, regulatory bodies need to facilitate foreign investment in the banking sector.

- Deposit insurance scheme did not contribute to banks' profitability; therefore, regulatory authorities need to establish an explicit insurance scheme and maintain close supervision over banks to discourage them from taking high risks. The World Bank Regulation and Supervision Survey which covered 180 countries for the period 1999-2011, compiled by Barth et al. (2013), revealed that the members of OIC countries need to improve their deposit insurance systems. Furthermore, policymakers must be attention to the fact that the establishment of an explicit deposit insurance system could delay the development of financial markets and of financial depth in general as reported by Cull et al. (2002). Additionally, Cubillas et al. (2012) argued that during a financial crisis deposit insurance scheme has a negative impact on the market discipline.

- Concentration correlated positively and significantly with profitability (NIM) this supported by a large volume of literature as seen in Table I. Therefore, policymakers need to maintain a small number of banks.
Determinants of conventional banks' profitability 
JEFAS

24,47

Even though this study had several implications to researchers and policymakers, more studies are required with data beyond 2008 . These studies could compare the profitability of conventional banks in OIC countries before and after the crisis. Also, future studies could include factors such as legal enforcement and governance.

\section{Notes}

1. The organization has 57 members, and the majority of the members are underdeveloped countries.

2. According to Goldberg (2014), 41 per cent of adults in developing countries have formal bank accounts, and the ones having accounts they rarely use it.

3. The number of banks in each country is small (Table II).

4. Several studies such as Nguyen (2011) and Alexiou and Sofokils (2009) used other operating income to total assets as a proxy for OBS activities.

5. The global spread of the financial crisis occurred at the end of 2008 through the impact on the results is negligible. In addition, developing and underdeveloped countries have a low degree of integration with world capital markets which will delay the effect of the crisis on those countries. Thus, the inclusion of 2007-2008 data will have minimal effect on the results of this study.

6. Comoros, Guinea-Bissau and Somalia not included because of data availability.

7. Their methodology is adopted by other researchers such as Hassan and Bashir (2003).

8. Olson and Mossman (2001), and Olson and Zoubi (2008) did not find evidence that nonlinear techniques outperformed linear models. Furthermore, linear regression is widely used in the literature, has produced good results and has even outperformed other techniques (Olson and Mossman, 2001).

9. Results are available upon request.

10. ROA also reflects how well bank managers use the bank's real investment resources to generate profits. ROA is chosen as the profitability measure over ROE because ROE disregards financial leverage and the risks associated with it.

11. Goldberg (2014) reported that "only 41 per cent of adults in developing countries have formal bank accounts, and many who do rarely use their accounts."

\section{References}

Abeysinghe, T. (2001), "Estimation of direct and indirect impact of oil price on growth", Economic Letters, Vol. 73 No. 2, pp. 147-153.

Abreu, M. and Mendes, V. (2001), "Commercial bank interest margins and profitability: evidence from some EU countries", paper presented at the Proceedings of the Pan-European Conference jointly organized by the IEFS-UK and University of Macedonia Economic and Social Sciences, Thessaloniki. 
Aburime, T. (2008), "Determinants of bank profitability: macroeconomic evidence from Nigeria”, SSRN Electronic Journal, 10.2139/ssm.1231064.

Akbaş, H. (2012), "Determinants of bank profitability: an investigation on Turkish banking sector", Öneri Dergisi, Vol. 10 No. 37, pp. 103-110.

Al-Bertazzi, U. and Gambacorta, L. (2009), "Bank profitability and the business cycle", Journal of Financial Stability, Vol. 5, pp. 393-409.

Alexiou, C. and Sofoklis, V. (2009), "Determinants of bank profitability: evidence from the Greek banking sector”, Economic Annals, Vol. 54 No. 182, pp. 93-118.

Alper, D. and Anbar, A. (2011), "Bank specific and macroeconomic determinants of commercial bank profitability: empirical evidence from Turkey", Business and Economics Research Journal, Vol. 2 No. 2, pp. 139-152.

Athanasoglou, P., Brissimis, S. and Delis, M. (2008), "Bank-specific, industry-specific and macroeconomic determinants of bank profitability", Journal of International Financial Markets, Institutions and Money, Vol. 18 No. 2, pp. 121-136.

Athanasoglou, P., Delis, M. and Staikouras, C. (2006), "Determinants of bank profitability in the South Eastern European region”, Journal of Financial Decision Making, Vol. 2, pp. 1-17.

Barth, J., Caprio, G. and Levine, R. (2013), "Bank regulation and supervision in 180 countries from 1999 to 2011”, Journal of Financial Economic Policy, Vol. 5 No. 2, pp. 111-219.

Ben Ameur, I. and Mhiri, S. (2013), "Explanatory factors of bank performance evidence from Tunisia", International Journal of Economics, Finance and Management, Vol. 2 No. 1, pp. 1-11.

Ben Khediri, K. and Ben-Khedhiri, H. (2009), "Determinants of Islamic bank profitability in the MENA region", International Journal of Monetary Economics and Finance, Vol. 2 Nos 3/4, pp. 409-426.

Ben Khedhiri, H., Casu, B. and Sheik Rahim, F. (2008), "Profitability and interest rates differentials in tunisian banking", Journal of Financial Decision Making, Vol. 4, pp. 33-43.

Ben Naceur, S. (2003), "The determinants of the Tunisian banking industry profitability: panel evidence", The 10th Annual Economic Research Forum Conference Proceedings, Economic Research Forum, Marrakech, 16-18 December, available at: www.erf.org.eg/CMS/uploads/pdf/ 1184755027_Ben_Naceur.pdf-rl (accessed 5 April 2010).

Ben Naceur, S. and Omran, M. (2011), "The effects of bank regulations, competition, and financial reforms on banks' performance", Emerging Markets Review, Vol. 12 No. 1, pp. 1-20.

Berger, A. (1995a), "The relationship between capital and earnings in banking", Journal of Money, Credit and Banking, Vol. 27 No. 2, pp. 432-456.

Berger, A. (1995b), "The profit-structure relationship in banking-tests of market-power and efficientstructure hypotheses", Journal of Money, Credit and Banking, Vol. 27 No. 2, pp. 404-431.

Berument, H., Ceylan, N. and Dogan, N. (2010), "The impact of oil price shocks on the economic growth of selected MENA countries", Energy Journal, Vol. 31 No. 1, pp. 149-176.

Bogdan, F. and Roman, A. (2015), "Internal and external determinants of commercial banks profitability: empirical evidence from Bulgaria and Romania", Annals of Faculty of Economics, University of Oradea, Faculty of Economics, Vol. 1 No. 1, pp. 896-904.

Borroni, M., Piva, M. and Rossi, S. (2016), Determinants of Bank Profitability in the Euro Area: Has Anything Changed? (N. Dises1619), Università Cattolica del Sacro Cuore, Dipartimentie Istituti di Scienze Economiche (DISCE).

Bourke, P. (1989), "Concentration and other determinants of bank profitability in Europe, North America and Australia”, Journal of Banking and Finance, Vol. 13, pp. 65-79.

Brunnermeier, M., Dong, G. and Palia, D. (2012), "Banks' non-interest income and systematic risk", Working Paper, Princeton University. 
JEFAS 24,47

Chen, S. and Liao, C. (2011), "Are foreign banks more profitable than domestic banks? Home- and hostcountry effects of banking market structure, governance, and supervision", Journal of Banking and Finance, Vol. 35, pp. 819-839.

Chiorazzo, V. and Milani, C. (2011), "The impact of taxation on bank profits: evidence from EU banks", Journal of Banking and Finance, Vol. 35 No. 12, pp. 3202-3212.

Chirwa, W. (2003), "Determinants of commercial banks' profitability in Malawi: a cointegration approach”, Applied Financial Economics, Vol. 13 No. 8, pp. 565-571.

Claeys, S. and Vennet, R. (2008), "Determinants of bank interest margins in central and Eastern Europe: a comparison with the west", Economic Systems, Vol. 32 No. 2, pp. 197-216.

Cubillas, E., Fonseca, A. and González, F. (2012), "Banking crises and market discipline: international evidence", Journal of Banking and Finance, Vol. 36 No. 8, pp. 2285-2298.

Cull, R., Senbet, L. and Sorge, M. (2002), "The effect of deposit insurance on financial depth: a crosscountry analysis", Quarterly Review of Economics and Finance, Vol. 42 No. 4, pp. 673-694.

Davis, P. and Obasi, U. (2009), "Deposit insurance systems and bank risk", Economics and Finance Working Paper Series, Working Paper No. 09-26.

Demirgüc-Kunt, A. and Huizinga, H. (1999), "Determinants of commercial bank interest margins and profitability: some international evidence", World Bank Economic Review, Vol. 13, pp. 379-408.

Demirgüç-Kunt, A. and Huizinga, H. (2000), "Financial structure and bank profitability", Working Paper series, No. 2430. World Bank.

Demirgüç-Kunt, A., Laeven, L. and Levine, R. (2004), "Regulations, market structure, institutions, and the cost of financial intermediation”, Journal of Money, Credit, and Banking, Vol. 36, pp. 593-622.

Dietrich, A., Wanzenried, G. and Cole, R. (2015), "Why are net-interest margins across countries so different?", SSRN Electronic Journal 10.2139/Ssrn.1542067.

Essayyad, M. and Madani, H. (2003), "Investigating bank structure of an open petroleum economy: the case of Saudi Arabia”, Managerial Finance, Vol. 29 No. 11, pp. 73-92.

Essayyad, M., Ramady, M. and Al-Hajji, M. (2003), "The determinants of bank profitability of a petroleum economy: the case of Saudi Arabia”, Petroleum Accounting and Financial Management Journal, Vol. 22 No. 3, pp. 69-102.

Ferrouhi, E.M. (2017), "Determinants of bank performance in a developing country: evidence from Morocco", Organizations and Markets in Emerging Economies, Vol. 8 No. 1, pp. 118-129.

Flamini, V., McDonald, C. and Schumacher, L. (2009), "The determinants of commercial bank profitability in Sub-Saharan Africa”, Working Paper, No. 09/15. International Monetary Fund.

Gelos, R. (2009), "Banking spreads in Latin America”, Economic Inquiry, Vol. 47 No. 4, pp. 796-814.

Ghosh, A. (2016), "Banking sector globalization and bank performance: a comparative analysis of low income countries with emerging markets and advanced economies", Review of Development Finance, Vol. 6 No. 1, pp. 58-70.

Goldberg, J. (2014), Products and Policies to Promote Saving in Developing Countries, IZA World of Labor.

Growe, G., DeBruine, M., Lee, J. and Tudón Maldonado, J. (2014), “The profitability and performance measurement of US regional banks using the predictive focus of the fundamental analysis research", Advances in Management Accounting, Vol. 24, pp. 189-237.

Haron, S. (2004), "Determinants of Islamic bank profitability", The Global Journal of Finance and Economics, Vol. 1, pp. 11-33.

Hassan, K. and Bashir, A. (2003), "Determinants of Islamic banking profitability", paper presented at the 10th ERF Annual Conference, Morocco, 16-18 December.

Heffernan, S. and Fu, M. (2008), "The determinants of bank performance in China”, Working paper series, No. WP-EMG-03-2008, Cass Business School, City University. 
Huseynov, F. (2009), "The determinants of bank interest margins when deposit insurance tied to interest rates: evidence from Azerbaijan", SSRN eLibrary, available at: http://papers.ssrn.com/ sol3/papers.cfm?abstract_id=1522285 (accessed 7 May 2010).

Imam, P. and Kpodar, K. (2010), "Islamic banking: how has it diffused”, IMF working paper 10/195.

Islam, M. and Nishiyama, S. (2016), "The determinants of bank profitability: dynamic panel evidence from South Asian countries", Journal of Applied Finance and Banking, Vol. 6 No. 3, p. 77.

Islamic Financial Services Board (IFSB) (2015), Islamic Financial Services Industry Stability Report, Islamic Financial Services Board, available at: http://ifsb.org/docs/IFSB $\% 20-\% 20$ IFSI $\%$ 20Stability\%20Report\%20TEXT\%20FINAL\%20(OUTPUT).pdf (accessed 29 May 2016).

Korytowski, M. (2018), "Banks' profitability determinants in post-crisis European union”, International Journal of Finance and Banking Studies (2147-4486), Vol. 7 No. 1, pp. 1-12.

Kosmidou, K., Tanna, S. and Pasiouras, F. (2005), "Determinants of profitability of domestic UK commercial banks: panel evidence from the period 1995-2002", 37th Annual Conference of the Money Macro and Finance Research Group Proceedings, Rethymno, 1-3 September, available at: http://images.coventry.ac.uk/bes/cubs/aboutthebusinessschool/Economicsfinanceandaccounting/ Documents/RP2008-4.pdf (accessed 2 August 2009).

Mamatzakis, E. and Remoundos, P. (2003), "Determinants of Greek commercial banks profitability: 1989-2000”, Spoudai, Vol. 53, pp. 84-94.

Menicucci, E. and Paolucci, G. (2016), "Factors affecting bank profitability in Europe: an empirical investigation", African Journal of Business Management, Vol. 10 No. 17, pp. 410-420.

Mungly, Y., Seetanah, B., Babajee, R. and Maraye, N. (2016), Determinants of Mauritian Commercial Banking Profitability Proceedings of the Fifth Asia-Pacific Conference on Global Business, Economics, Finance and Social Sciences.

Nguyen, J. (2011), "Market concentration and other determinants of bank profitability: evidence from panel data", International Research Journal of Finance and Economics, Vol. 70, pp. 7-17.

Noman, A., Chowdhury, M., Chowdhury, N., Kabir, M. and Pervin, S. (2015), "The effect of bank specific and macroeconomic determinants of banking profitability: a study on Bangladesh", International Journal of Business and Management, Vol. 10 No. 6, p. 287.

Olson, D. and Mossman, C. (2001), "Cross-correlations and predictability of stock returns", Journal of Forecasting, Vol. 20 No. 2, pp. 145-160.

Olson, D. and Zoubi, T. (2008), "Using accounting ratios to distinguish between Islamic and conventional banks in the GCC region”, The International Journal of Accounting, Vol. 43 No. 1, pp. $45-65$.

Pasiouras, F. and Kosmidou, K. (2007), "Factors influencing the profitability of domestic and foreign commercial banks in the European union”, Research in International Business and Finance, Vol. 21 No. 2, pp. 222-237.

Petria, N., Capraru, B. and Ihnatov, I. (2015), "Determinants of banks' profitability: evidence from EU 27 banking systems", Procedia Economics and Finance, Vol. 20, pp. 518-524.

Poghosyan, T. and Hesse, H. (2009), "Oil prices and bank profitability: evidence from major oil exporting countries in the Middle East and North Africa”, Working paper series, No. 09/220. IMF.

Rahman, M., Hamid, K. and Khan, A. (2015), "Determinants of bank profitability: empirical evidence from Bangladesh”, International Journal of Business and Management, Vol. 2 No. 8, pp. 135-150.

Rekik, M. and Kalai, M. (2018), "Determinants of banks' profitability and efficiency: empirical evidence from a sample of banking systems", Journal of Banking and Financial Economics, Vol. 2018 No. 1, pp. 5-23.

Saona, P. (2016), "Intra-and extra-bank determinants of Latin American banks' profitability", Revista Mexicana de Economía y Finanzas, Vol. 11 No. 1, pp. 1-27. 
JEFAS 24,47

Soyemi, K., Akinpelu, L. and Ogunleye, O. (2013), “The determinants of profitability among deposit money banks (DMBs) in Nigeria post consolidation", Global Advanced Research Journal of Economic, Accounting and Finance, Vol. 2 No. 5, pp. 93-103.

Srairi, S. (2009), "Factors influencing the profitability of conventional and Islamic commercial banks in GCC countries", Review of Financial Economics, Vol. 13, pp. 5-30.

Staikouras, C. and Wood, G. (2003), "The determinants of bank profitability in Europe”, International Business and Economics Research Journal, Vol. 3, pp. 57-68.

Sufian, F. (2012), "Determinants of bank profitability in developing economies: empirical evidence from the South Asian banking sectors", Contemporary South Asia, Vol. 20 No. 3, pp. 375-399.

Sun, P., Mohamad, S. and Ariff, M. (2017), "Determinants driving bank performance: a comparison of two types of banks in the OIC", Pacific-Basin Finance Journal, Vol. 42, pp. 193-203.

Tariq, W., Usman, M., Mir, H., Aman, I. and Ali, I. (2014), "Determinants of commercial banks profitability: empirical evidence from Pakistan", International Journal of Accounting and Financial Reporting, Vol. 4 No. 2, pp. 1-22.

Valverde, S. and Fernández, F. (2007), "The determinants of bank margins in European banking", Journal of Banking and Finance, Vol. 31, pp. 2043-2063.

Vithyea, Y. (2014), "The linkage between bank net interest margins and non-interest income: the case of the Cambodian banking industry", MPRA Paper 58230, University Library of Munich.

Wahidudin, A., Subramaniam, U. and Kamaluddin, P. (2012), "Determinants of profitability - a comparative analysis of Islamic banks and conventional banks in ASEAN countries", Social Science Research Network n. 2251602, available at: www.ssrn.com/ (accessed 9 November 2018).

Yanikkaya, H., Gumus, N. and Pabuccu, Y. (2018), "How profitability differs between conventional and Islamic banks: a dynamic panel data approach", Pacific-Basin Finance Journal, Vol. 48, pp. 99-111.

Yao, H., Haris, M. and Tariq, G. (2018), "Profitability determinants of financial institutions: evidence from banks in Pakistan", International Journal of Financial Studies, Vol. 6 No. 2, p. 53.

Yüksel, S., Mukhtarov, S., Mammadov, E. and Özsarı, M. (2018), "Determinants of profitability in the banking sector: an analysis of post-soviet countries", Economies, Vol. 6 No. 3, p. 41.

Zantioti, E. (2009), "Does Islamic bank performance differ by region? A study on the characteristics that impact profitability within Islamic banking among its main geographical regions", $\mathrm{PhD}$ thesis, Stockholm School of Economics, Stockholm.

\section{Further reading}

Demirgüç-Kunt, A. and Detragiache, E. (2002), "Does deposit insurance increase banking system stability? An empirical investigation”, Journal of Monetary Economics, Vol. 49 No. 7, pp. 1373-1406.

Demirgüç-Kunt, A., Karacaovali, B. and Laeven, L. (2005), "Deposit insurance around the world: a comprehensive database", Working paper series, No. 3628. World Bank.

Demirgüç-Kunt, A., Laeven, L. and Levine, R. (2003), "The impact of bank regulations, concentration, and institutions on bank margins", Working Paper series, No. 3030. World Bank.

\section{Corresponding author}

Ahmad Al-Harbi can be contacted at: atalharbi@yahoo.com.au

For instructions on how to order reprints of this article, please visit our website:

www.emeraldgrouppublishing.com/licensing/reprints.htm

Or contact us for further details: permissions@emeraldinsight.com 